\title{
Sammlluttg Bsöiłhen
}

\section{Die \\ Cordillerenitaaten}

Von

\section{Dr. Bilhelm Sievers}

ßrofelīor an der ltniverjität Bieß̄en

\author{
3weites Bänochen
}

Ecuador, Colombia und Benezuela

Mit 7 Textabbildungen, 16 Tajeln und einer farte in Sithographie

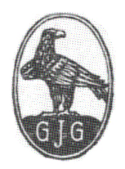

$$
\text { Berlin und } 2 e i p z i g
$$

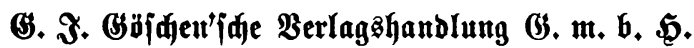
1913 


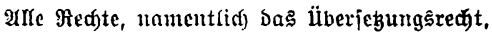
ven ber Berlagshandung vorbebalten.

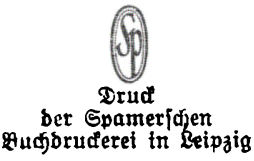

